\title{
\begin{tabular}{|l|l|}
\hline JURNAL EKONOMI DAN MANAJEMEN \\
\hline
\end{tabular} \\ P-ISSN: 2598-9022/ E-ISSN: 2598-9618 \\ Available at: http://e-journal.unipma.ac.id/index.php/capital
}

\section{Pengaruh Return On Assets dan Ukuran Perusahaan Terhadap Struktur Modal PT.Mayora Indah Tbk}

\author{
Rahkutin $^{1)}$, Alwi $^{2)}$ \\ ${ }^{1}$ Sekolah Tinggi Ilmu Ekonomi (STIE) Bima \\ email: penulis_1 rahkutin16.stiebima@gmail.com \\ ${ }^{2}$ Sekolah Tinggi Ilmu Ekonomi (STIE) Bima \\ email: penulis_2alwi.stiebima@yahoo.com
}

\begin{abstract}
This study aims to (1) study and analyze the effect of Return On Assets on capital structure at PT.Mayora Indah Tbk, (2) study and analyze the influence of company size on capital structure at PT.Mayoran Indah Tbk, (3) find and analyze the influence Return On Assets and Company Size on the capital structure at PT.Mayora Indah Tbk. The population used in this study is PT.Mayora Indah Tbk's financial statements published on the Stock Exchange. The sampling technique used is the purposive sampling method. Data analysis techniques used are (1) classic assumption test (2) multiple linear regression, (3) multiple coordination coefficients, (4) coefficient of determination, (5) $t$ test and f test. The results of the study indicate that the Return On Assets are partially partial to the capital structure, while the size of the company does not conflict partially with the capital structure, (f test) shows that there is a significant influence between the Return on Assets and the size of the company on the capital structure.
\end{abstract}

Keywords: Return On Assets, Company Size, Capital Structure

\begin{abstract}
Abstrak
Penelitian ini bertujuan untuk (1) mengetahui dan menganalisis pengaruh Return On Asset terhadap struktur modal pada PT.Mayora IndahTbk, (2) mengetahui dan menganalisis pemgaruh Ukuran perusahaan terhadap struktur modal pada PT.Mayoran Indah Tbk, (3) mengetahui dan menganalisis pengaruh Return On Asset dan Ukuran Perusahaan terhadap struktur modal pada PT.Mayora Indah Tbk. Populasi yang digunakan dalam penelitian ini adalah laporan keuangan PT.Mayora Indah Tbk yang di Publish di Bursa Efek,Teknik sampling yang digunakan yaitu metode purposive sampling. Teknik analisa data yang digunakan yaitu (1) uji asumsi klasik (2) regresi linear berganda, (3) koefisien korelasi berganda, (4) koefisien determinasi, (5) uji t dan uji f. Hasil penenlitian menunjukkan bahwa Return On Asset secara parsial tidak berpengaruh secara parsial terhadap struktur modal, sedangkan Ukuran Perusahaanberpengaruh secara signifikan terhadap struktur modal, (uji f) menunjukkan terdapat pengaruh yang signifikan antara Return On Asset dan Ukuran Perusahaan terhadap struktur modal.
\end{abstract}

Kata Kunci: Return On Asset, Ukuran perusahaan, Struktur Modal

\section{A. PENDAHULUAN}

Pada dasarnya setiap perusahaan memiliki tujuan yang sama yaitu mendapatkan laba, dalam mencapai tujuan tersebut perusahaan memerlukan dana atau modal untuk melakukan analisis keuangan dan melaksanakan kegiatan operasionalnya. Perusahaan perlu melakukan analisis keuangan untuk mengetahui kekuatan dan kelemahan kondisi keuangan perusahaan.Cara yang dapat di lakukan untuk menganalisis keuangan perusahaan adalah dengan analisis rasio keuangan. 
Salah satu rasio keuangan yang dapat digunakan adalah rasio Profitabiltas, Dalam penelitian ini rasio profitabilitas yang digunakan adalah Return On Assets (ROA), dikarenakan ROA mencerminkan tingkat pengembalian dari modal yang diinvestasikan oleh perusahaan dalam keseluruhan aktiva. Semakin tinggi nilai ROA maka laba yang dihasilkan akan semakin tinggi sehingga semakin banyak kas internal yang dimiliki sebaliknya kebutuhan akan dana eksternal akan berkurang.

Ukuran perusahaan menggambarkan besar kecilnya suatu perusahaan yang ditujukan pada total aktiva, jumlah penjualan, rata-rata penjualan dan rata-rata total aktiva (Bambang Riyanto, 2001). Menurut Mas'ud (2008) semakin besar ukuran perusahaan yang diukur dengan total asset, maka perusahaan akan menggunakan utang dalam jumlah yang besar pula. Perusahaan yang ukurannya relatif besar pun akan cenderung menggunakan dana eksternal yang semakin besar, Dan Struktur modaldalam penelitian ini diukur dengan menggunakan rasio Debt To Equity Ratio (DER) yang merupakan rasio yang digunakan untuk mengukur tingkat penggunaan utang terhadap total modal sendiri yang dimiliki perusahaan.

Kondisi atau kinerja Keuangan PT. Mayora Indah Tbk sendiri tercatat oleh perseroan kurang gemilang, Laba bersih mengalami penurunan yang drastic hal itu terlihat pada tahun 2014 mengalami penurunan laba yang sangat drastis. Perseroan mencatatkan ditahun 2014, laba bersih turun 59,56 persen menjadi Rp. 409,618 miliar pada tahun 2014 dari periode sama sebelumnya Rp. 1.01 triliun. Hal yang menarik meski laba bersih di tahun tersebut turun, justru penjualan bersih naik 17,9 persen menjadi Rp 14,16 triliun. Proyeksi penurunan laba bersih ini agak mengagetkan lantaran PT. Mayora Indah Tbk justru masih optimistis dengan kinerja penjualan, laba bersih,laba kotor maupun laba usaha dimasa yang akan datang.

Untuk penelitian penulis ingin melihat (1) Untuk mengetahui dan menganalisis tingkat Return On Asset Dan Struktur Modal Pada PT. Mayora Indah Tbk (2) Untuk mengetahui dan menganalisis tingkat Ukuran perusahaan Dan Struktur Modal Pada PT. Mayora Indah Tbk (3) Untuk mengetahui dan menganalisis pengaruh yang signifikan antara Return On Assetdan Ukuran Perusahaan terhadap struktur modal PT. Mayoran IndahTbk. 
Berdasarkan uraian diatas maka penulis tertarik untuk melakukan penelitian dengan judul "Pengaruh Return On Asset Dan Ukuran Perusahaan Terhadap Struktur Modal Pada PT. Mayora Indah Tbk”.

\section{B. TINJAUAN PUSTAKA}

\section{ROA ( Return On Assets )}

Pengukuran kinerja keuangan dalam penelitian ini adalah dengan rasio profitabilitas. Profitabilitas diukur dengan Return On Asset (ROA) yang menunjukkan seberapa banyak laba bersih yang dapat dan diperoleh dari seluruh kekayaan yang dimiliki oleh suatu perusahaan. Disamping itu, hasil pengembalian investasi menunjukkan produktivitas dari seluruh dana perusahaan, baik modal pinjaman maupun modal sendiri. Semakin kecil (rendah) rasio ini, semakin kurang baik, demikian pula sebaliknya. Dan rata-rata industri untuk return on asset (ROA) adalah $30 \%$. (Kasmir, 2017:203).

Rumus Return on asset :

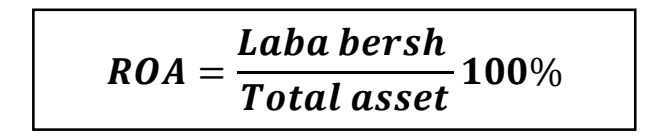

Tabel 1.1

Tabel Standard Kriteria Return On Asset

\begin{tabular}{|c|c|}
\hline ROA & Kriteria \\
\hline$>1,5 \%$ & Sangat sehat \\
\hline $\mathbf{1 , 2 5} \%<$ ROA $\leq 1,5 \%$ & Sehat \\
\hline $\mathbf{0 , 5}<$ ROA $\leq \mathbf{1 , 2 5} \%$ & Cukup Sehat \\
\hline $\mathbf{0 \%}, \mathbf{R O A} \leq \mathbf{0 , 5} \%$ & Kurang Sehat \\
\hline ROA $\leq \mathbf{0} \%$ & Tidak Sehat \\
\hline
\end{tabular}

Sumber : Kasmir (2008)

\section{Ukuran Perusahaan}

Perusahaan pada ukuran yang besar akan selalu membutuhkan modal yang semakin besar demikian juga sebaliknya perusahaan pada ukuran kecil, kebutuhan terhadap modal juga semakin kecil. Menurut Hery (2017:11) bahwa ukuran perusahaan menggambarkan besar kecilnya suatu perusahaan yang dapatdinyatakan dengan total aset ataupun total penjualan bersih. Semakin besar total aset maupun penjualan maka semakin besar pula ukuran suatu perusahaan. Semakin besar aset maka semakin besar 82 | C A P I T A L, V O L UME 4, NOMOR 1, S EPTEMBER 2020 
modal yang ditanam, sementara semakin banyak penjualan maka semakin banyak juga perputaran uang dalam perusahaan.sedangkan menurut Saidi (2004: 50) dalam penelitian Salehudin (2015:17) bahwa ukuran perusahaan merupakan ukuran atau besarnya aset yang dimiliki perusahaan.

\section{Struktur Modal}

Struktur modal adalah pembelanjaan permanen di mana mencerminkan perimbangan antara utang jangka panjang dengan modal sendiri (Riyanto, 2010:22).Sementara definisi struktur modal menurut Sudana (2011:164) adalah stuktur modal (capital structure) berkaitan pembelanjaan jangka panjang suatu perusahaan yang diukur dengan perbandingan utang jangka panjang dengan modal sendiri.Dari pengertian tersebut dapat disimpulkan bahwa struktur modal adalah bagian dari struktur keuangan yang merupakan perimbangan antara utang jangka panjang dengan dengan modal sendiri yang menjadi sumber pembiayaan dari suatu perusahaan.

Rumus Debt To Equity Ratio

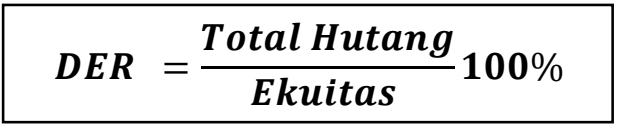

Tabel 1.2

Kriteria Pengukuran DER

\begin{tabular}{|c|c|}
\hline Presentase & Keterangan \\
\hline$<90 \%$ & Sehat \\
\hline$>90 \%$ & Tidak sehat \\
\hline Sumber : Kasmir (2008)
\end{tabular}

\section{METODE PENELITIAN}

Jenis penelitian ini adalah penelitian Kuantitatif. Populasi dalam penelitian ini adalah laporan keuangan PT. Mayora Indah Tbk. yang terdiri dari Laporan Neraca, dan Laporan Laba/Rugi, periode 1990-2018 atau selama 22 tahun ( Dua Puluh Tiga ) tahun selama perusahaan tersebut mulai terdaftar di bursa efek Indonesia. Sampel dalam penelitian ini adalah Laporan Keuangan yang terdiri dari Laporan Neraca dan Laba/Rugi periode 2012 sampai dengan 2018 atau selama, 7 ( Tujuh Tahun ).Dalam Penelitian ini sampling yang digunakan yaitu purposive sampling. Instrumen dalam penelitian ini menggunakan daftar tabel, yang terdiri atas data Return on asset, Ukuran 
Perusahaan, dan Debt to equity ratio. Tehnik Pengumpulan data yang digunakan yaitu Studi Pustaka, dan Dokumentasi.

Selanjutnya tehnik analisa data yang digunakan adalah Uji asumsi klasik, uji regresi berganda, uji korelasi, uji koefisien determinasi, uji t (2 pihak), uji F.

\section{HASIL DAN PEMBAHASAN}

\section{UJI ASUMSI KLASIK}

\section{Uji normalitas}

\section{Gambar 1.1}

\section{Hasil Uji Normalitas}

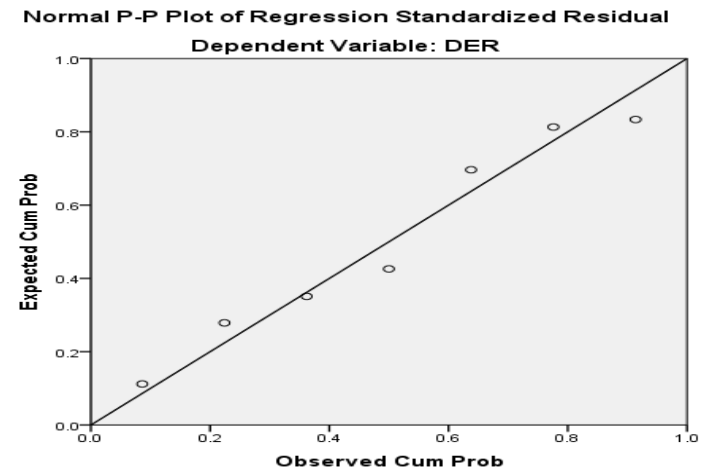

Dari gambar diatas dapat dijelaskan bahwa residual data terdistribusi secara normal, dengan menyebar disekitar garis diagonal dan mengikuti arah garis diagonal, dan tidak menjauhigaris diagonal maka dapat di tarik kesimpulkan bahwa dalam model regresi dalam penelitian memenuhi asumsi normalitas.

\section{Uji multikolinearitas}

Tabel 4.1

Hasil UJI Multikolinearitas

PT. Mayora Indah Tbk

\begin{tabular}{|c|c|c|c|c|c|c|c|}
\hline & & Coeffic & ients ${ }^{a}$ & & & & \\
\hline \multirow[t]{2}{*}{ Model } & \multicolumn{2}{|c|}{$\begin{array}{l}\text { Unstandardized } \\
\text { Coefficients }\end{array}$} & \multirow{2}{*}{$\begin{array}{c}\text { Standardize } \\
\text { d } \\
\text { Coefficients }\end{array}$} & \multirow[t]{2}{*}{$\mathrm{t}$} & \multirow[t]{2}{*}{ Sig. } & \multicolumn{2}{|c|}{$\begin{array}{l}\text { Collinearity } \\
\text { Statistics }\end{array}$} \\
\hline & B & Std. Error & & & & $\begin{array}{c}\text { Toleranc } \\
\mathrm{e}\end{array}$ & VIF \\
\hline (Constant) & 3804.100 & 260.473 & & 14.605 & .000 & & \\
\hline $\mathrm{ROA}$ & -1.556 & .914 & -.115 & -1.703 & .164 & .848 & 1.179 \\
\hline
\end{tabular}

84 | C A P I T A L, V O L UME 4, NOMOR 1, S E P T EMBER 2020 


\begin{tabular}{|l|l|l|l|l|l|l|l|}
\hline $\begin{array}{l}\text { UKURAN } \\
\text { PERUSAHAAN }\end{array}$ & -121.834 & 8.764 & -.942 & -13.901 & .000 & .848 & 1.179 \\
\hline
\end{tabular}

a. Dependent Variable: DER

Dari tabel diatas diperoleh angka tolerance 0,848 dan angka VIF 1,179 nilai tersebut menunjukan bahwa nilai Tolerance $0,848>0,100$ serta nilai VIF $1,179<$ 10,00, Maka data penelitian diatas dapat dikatakan tidak terdapat masalah atau gejala multikolinearitas.

\section{Uji Heteroskedastisitas}

Tabel 4.2

Hasil UJI Heteroskedastisitas

PT. Mayora Indah Tbk

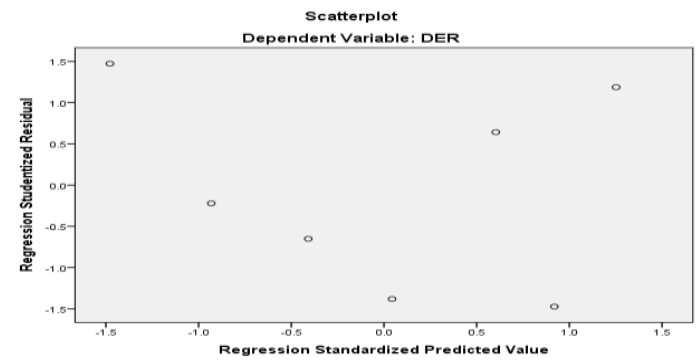

Dari gambar diatas dapat diketahui bahwa tidak terjadi heterosdastisitas sebab tidak ada pola yang jelas serta titik-titik menyebar diatas dan dibawah angka 0 pada sumbu Y sehingga dapat dikatakan uji heteroskedastisitas terpenuhi.

\section{Uji Autokorelasi}

Tabel 4.3

Hasil UJI Autokorelasi

PT. Mayora Indah Tbk

Model Summaryb

\begin{tabular}{|l|l|r|r|r|r|}
\hline $\begin{array}{l}\text { Mode } \\
\text { I }\end{array}$ & $\mathrm{R}$ & R Square & $\begin{array}{c}\text { Adjusted R } \\
\text { Square }\end{array}$ & $\begin{array}{c}\text { Std. Error of the } \\
\text { Estimate }\end{array}$ & $\begin{array}{c}\text { Durbin- } \\
\text { Watson }\end{array}$ \\
\hline 1 & $.992^{\mathrm{a}}$ & .984 & .977 & 5.250408 & .883 \\
\hline
\end{tabular}

a. Predictors: (Constant), UKURAN PERUSAHAAN, ROA

b. Dependent Variable: DER

Dari tabelmodel Summary diatas menunjukan besarnya angka DurbinWatson sebesar 0,883.dan diperoleh nilai dalam tabel DW untuk " $\mathrm{k}=2$ " dan " $\mathrm{N}=7$ " 
dan besarnya $\mathrm{dL}=0.4672$ Dan $\mathrm{Du}=1.8964$ nilai $\mathrm{DW}=0,883$ Maka dapat disimpulkan tidak terjadi gejala autokorelasi.

\section{Uji Regresi Linear Berganda}

Tabel 4.4

Hasil UJI Regresi Linear Berganda

PT. Mayora Indah Tbk

\begin{tabular}{|c|c|c|c|c|c|c|}
\hline \multicolumn{7}{|c|}{ Coefficients $^{a}$} \\
\hline \multirow{2}{*}{\multicolumn{2}{|c|}{ Model }} & \multicolumn{2}{|c|}{ Unstandardized Coefficients } & \multirow{2}{*}{$\begin{array}{c}\text { Standardized } \\
\text { Coefficients } \\
\text { Beta }\end{array}$} & \multirow[b]{2}{*}{$\mathrm{t}$} & \multirow[b]{2}{*}{ Sig. } \\
\hline & & $\mathrm{B}$ & Std. Error & & & \\
\hline \multirow[t]{3}{*}{1} & (Constant) & 3804.100 & 260.473 & & 14.605 & .000 \\
\hline & ROA & -1.556 & .914 & -.115 & -1.703 & .164 \\
\hline & UKURAN PERUSAHAAN & -121.834 & 8.764 & -.942 & -13.901 & .000 \\
\hline
\end{tabular}

Berdasarkan hasil pengujian dari tabel diatas dapat dibuat model persamaan regresi sebagai berikut :

$\mathrm{Y}=3804,100-1,556 \mathrm{X} 1-121.834 \mathrm{X} 2$

Model persamaan regresi diatas menunjukan nilai konstanta $(\alpha)$ sebesar3804,100 hal ini berarti jika Return On Assets Dan Ukuran Perusahaan bernilai 0, maka jumlah Debt to Equity Ratiobernilai sebesar Rp. 3804,100 dengan asumsi faktor lainnya bernilai tetap. Sedangkan hasil uji regresi linear berganda untuk variabel independen dapat dijelaskan sebagai berikut :

a. Nilai koefisien (B) untuk ROA menunjukan angka yaitu - 1,556hal ini berarti setiap peningkatan 1\%, Return On Assets, maka akan menurunkan Debt to Equity Ratio sebesar 1,556\% dengan asumsi faktor lain bernilai tetap.

b. Nilai koefisien (B) untuk Ukuran Perusahaan menunjukan angka yaitu 121.834hal ini berarti setiap peningkatan 1\%,Ukuran Perusahaan, maka akan menurunkan Debt to Equity Ratio sebesar 121.834\% dengan asumsi faktor lain bernilai tetap. 


\section{Koefisien korelasi berganda}

Tabel 4.5

Hasil UJI korelasi berganda

PT. Mayora Indah Tbk

\begin{tabular}{|l|r|r|r|r|r|}
\hline Model & R & R Square & $\begin{array}{c}\text { Adjusted R } \\
\text { Square }\end{array}$ & $\begin{array}{c}\text { Std. Error of the } \\
\text { Estimate }\end{array}$ & Durbin-Watson \\
\hline 1 & $.992^{\mathrm{a}}$ & .984 & .977 & 5.250408 & .883 \\
\hline
\end{tabular}

a. Predictors: (Constant), UKURAN PERUSAHAAN, ROA

b. Dependent Variable: DER

Dari tabel diatas, angka $\mathrm{R}$ sebesar 0,992 menunjukan bahwa korelasi atau hubungan antara variabel dependen yaitu laba dengan 2 variabel independennya yaitu ukuran perusahaan dan ROA sangat kuat.

\section{Uji Koefisien Determinasi $\left(\mathbf{R}^{2}\right)$}

Tabel 4.6

Hasil UJI Koefisien Determinasi $\left(\mathbf{R}^{2}\right)$

PT. Mayora Indah Tbk

\begin{tabular}{|l|r|r|r|r|r|}
\hline Model & R & R Square & $\begin{array}{c}\text { Adjusted R } \\
\text { Square }\end{array}$ & $\begin{array}{c}\text { Std. Error of the } \\
\text { Estimate }\end{array}$ & Durbin-Watson \\
\hline 1 & $.992^{\mathrm{a}}$ & .984 & .977 & 5.250408 & .883 \\
\hline
\end{tabular}

a. Predictors: (Constant), UKURAN PERUSAHAAN, ROA

Sumber data menggunakan Spss 21

Dari tabel diatas nilai $\mathrm{R}$ Square menunjukan angka sebesar 0,984. Hal ini berarti bahwa besar kemampuan ke dua variabel independen terhadap variabel dependen yang dapat dijelaskan oleh persamaan ini adalah sebesar 98,4\% sedangkan sisanya sebesar 1,6\% dipengaruhi oleh variabel lain yang tidak dimasukkan dalam model penelitian ini. 


\section{Uji F (Simultan)}

\begin{tabular}{|c|c|c|c|c|c|c|}
\hline \multicolumn{7}{|c|}{$\begin{array}{c}\text { Tabel } 4.7 \\
\text { Hasil UJI F (Simultan) } \\
\text { PT. Mayora Indah Tbk } \\
\text { ANOVAa }\end{array}$} \\
\hline Model & & Sum of Squares & $\mathrm{df}$ & Mean Square & $\mathrm{F}$ & Sig. \\
\hline \multirow{3}{*}{1} & Regression & 6974.516 & 2 & 3487.258 & 126.502 & $.000^{\mathrm{b}}$ \\
\hline & Residual & 110.267 & 4 & 27.567 & & \\
\hline & Total & 7084.783 & 6 & & & \\
\hline
\end{tabular}

a. Dependent Variable: DER

b. Predictors: (Constant), UKURAN PERUSAHAAN, ROA

Dari perhitungan tabel diatas diperoleh nilai $F_{\text {hitung }}>F_{\text {tabel }}$ atau 126,502> 9,55 yang berarti terima $\mathrm{H} 0$. Hasil pengujian secara simultan atau uji $\mathrm{F}$ dapat disimpulkan bahwa Return On AssetdanUkuran Perusahaansecara bersama-sama atau secaracsimultan berpengaruh terhadap Debt to Equity Ratio Pada PT Mayora Indah Tbk.

Uji $t 2$ pihak (Parsial)

Tabel 4.8

Hasil UJI t 2 pihak (Parsial)

PT. Mayora Indah Tbk

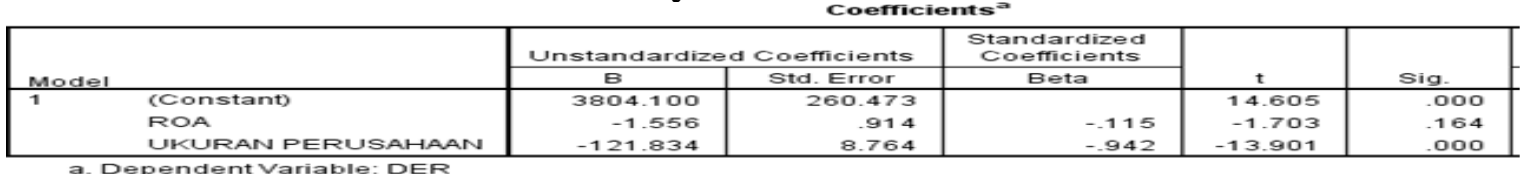

Sumber data menggunakan Spss 21

\section{Return On Asset (ROA) Berpegaruh Terhadap Struktur modal}

Dari tabel diatas diperolehnilai sig 0.164 maka dapat disimpulkan bahwa Return On Asset secara parsial tidakberpengaruh secara signifikan terhadap Debt to Equity Ratio pada PT Mayora Indah Tbk.

\section{Ukuran Perusahaan Secara Parsial Berpegaruh Terhadap Struktur modal}

Dari tabel diatas diperoleh sig 0.000.makadapat disimpulkan bahwa Ukuran Perusahaan secara parsial berpengaruh secara signifikan terhadap Debt to Equity Ratio Pada PT Mayora Indah Tbk. 


\section{Simpulan}

Berdasarkan hasil penelitian maka dapat diambil kesimpulan bahwa Return On Asset secara parsial tidak berpengaruh terhadap Struktur Modal.Ukuran Perusahaan secara parsial berpengaruh terhadap Struktur modal, dan Uji F atau Uji Secara Simultan Return On Asset dan Ukuran Perusahaan berpengaruh dan Signifikan terhadap Struktur Modal.

\section{Saran}

Berdasarkan hasil kesimpulan, maka penelitian memberikan saran, sebagai berikut Bagimanajemen perusahaan di sarankan agar dapat lebih memaksimalkan lagi tingkatpendapatan dan total asset yang di miliki, karena indikator ini mempengaruhi struktur modal perusahaan. Bagi peneliti selanjutnya, disarankan sebaiknya di sempurnakan lagi keterbatasan dalam peneliti iniyaitu dengan menambah variabel lain yang mempengaruhi struktur modal perusahaan dan Sampek penelitian ditambahkan lagi.

\section{DAFTAR PUSTAKA}

Atiqoh, Z., \& Asyik, N. F. (2016). Pengaruh Kinerja Keuangan, Pertumbuhan Penjualan Dan Kepemilikan Saham Terhadap Struktur Modal. Jurnal Ilmu Dan Riset Akuntansi.

Hery. (2017). Kajian Riset akuntansi mengulas berbagai hasil penelitian terkini dalam bidang akuntansi dan keuangan. In Jakarta : PT Grasindo.

Husnan, S., \& Pudjiastuti, E. (1994). Dasar-dasar Manajemen Keuangan. Yogyakarta: UPP AMP YKPN. Ekonomi. https://doi.org/http://dx.doi.org/10.1186/s12913-0172111-9

Kasmir. (2014). Analisis Laporan Keuangan, Edisi Satu, Cetakan Ketujuh. In Raja Grafindo Persada.

Kusna, I., \& Setijani, E. (2018). Analisis Pengaruh Kinerja Keuangan, Growth Opportunity Dan Ukuran Perusahaan Terhadap Struktur Modal Dan Nilai 89|C A P I T A L, V O L UME 4, NOMOR 1, S EPTEMBER 2020 
Perusahaan. JURNAL MANAJEMEN DAN KEWIRAUSAHAAN. https://doi.org/10.26905/jmdk.v6i1.2155

Maulina, G., Nuzula, N. F., \& Nurlaily, F. (2018). Pengaruh Faktor-Faktor Penentu Struktur Modal Terhadap Struktur Modal (Studi pada Perusahaan Manufaktur yang Terdaftar di Bursa Efek Indonesia periode 2014-2016). Jurnal Administrasi Bisnis Fakultas Ilmu Administrasi Universitas Brawijaya Malang.

Munirah Ira, Nurkholis, \& Sutrisno. (2012). Sutrisno. Manajemen Keuangan: Teori Konsep \& Aplikasi.

Sugiyono. (2012). Metode Penelitian Kuantitatif, Kualitatif dan $\mathrm{R}$ \& D.Bandung:Alfabeta. Metode Penelitian Kuantitatif, Kualitatif Dan $R \quad \&$ D.Bandung:Alfabeta. https://doi.org/10.1017/CBO9781107415324.004 